\title{
АНГЛІЙСЬКІ НЕОЛОГІЗМИ КОРОНАВІРУСНОЇ КРИЗИ
}

У статті досліджено англійські неологізми, щзо з'явилися на тлі пандемії коронавірусу. Увагу присвячено вивченню словотвірного потенціалу неологізмів коронавірусної термінології, зокрема проаналізовано такі словотвірні механізми як телескопія, словоскладання, абіксація, конверсія, абревіащія, афереза. Дослідження показало, щь продуктивними словотвірними механізмами для иьвого виду неологізмів є словоскладання (46\% зафіксованих неологізмів), телескопія (33\%) та абіксація (15\%). Подальші наукові розвідки плануємо присвятити вивченню інших сфер, у яких формуються сучасні англійські неологізми (туризму, екології, харчуванню, родинним відносинам, моді тощо), зокрема детально проаналізувати такі способи формування неологізмів як усічення, конверсія та абревіація.

Ключові слова: неологізм, коронавірусна термінологія, телескопія, словоскладання, афіксація, конверсія, абревіація, афереза.

\section{Sandyha L., Svyrydiuk T., Romanchuk S. English Neologisms of the Coro-} navirus Pandemic. The present article investigates English neologisms denoting Covid-19 and the adjacent phenomena. The vocabulary coined in this sphere has not been studied as a complex phenomenon yet as it is absolutely new. The coronavirus pandemic which started at the end of 2019 has given rise to numerous neologisms denoting new channels of communication (quarantine bubbles, quaranteam, teletherapy, tele-socializing, Zoombombing), categories of people (coronnials, quarantrolls, covidiots, anti-maskers, space marshals), occupations (WFH, revenge spending, spendemic), tendencies (quarantrends, lockdown tache, Blursdays, Zoomwear, zumping) etc. Moreover, the processes of mass digitalization and popularization of social media have created favorable conditions for the invention and fast sharing of the Covid-19 terminology between online users. Within the framework of the article the derivational potential of the Covid-19 neologisms is studied, in particular such word-forming mechanisms as blending, compounding, affixation, abbreviation, clipping, and conversion are analyzed. The research has shown that compounding (46\% of the neologisms under consideration), blending (33\%), and affixation (15\%) are productive word-forming mechanisms for this kind of coinages, whereas abbreviation, clipping, and conversion are not. As regards compounding, the $N+N$ pattern is the most generative in such coinages (63\%). Conclusions are made and suggestions for further research are given. Due to the fact that the world health crisis is yet to continue, many other neologisms denoting it and the adjacent phenomena are yet to appear. Our future research will be devoted to the analysis of other spheres in which English neologisms are coined, namely social media, modern technologies, 
sustainable development, green tourism, culinary trends, family, fashion, etc. The neologisms formed by means of acronymy, conversion, and clipping will be studied in more detail as well.

Keywords: neologism, Covid-19 terminology, blending, compounding, affixation, conversion, abbreviation, clipping.

\section{Вступ}

Пандемія коронавірусу, яка охопила весь світ наприкінці 2019 року, стала новим продуктивним джерелом неологізмів. Роберт Лоусон, професор соціолінгвістики з Бірмінгемського університету стверджує, що нова лексика, яка увійшла до складу англійської мови під час світової кризи коронавірусу, слугує інструментом, за допомогою якого люди висловлюють свої переживання про одну з найбільш серйозних пандемій останніх часів. Цей вокабуляр, який створюється спільними зусиллями й позначає новий культурний феномен, виконує функцію «соціального клею». 3 огляду на те, що люди позбавлені регулярної соціальної взаємодії, існування спільної мови $є$ важливим інструментом для того, щоб залишатися на зв'язку (Lawson, 2020).

Професор Лоусон зауважує, що поширення коронавірусної термінології пришвидшується завдяки процесу діджиталізації та активного спілкування в соціальних мережах. Це свідчить про те, що наразі люди мають більше можливостей створювати неологізми й ділитися ними в численних онлайн-спільнотах (Lawson, 2020).

Неологізми, що віддзеркалюють соціальні й культурні інновації, завжди були в центрі уваги таких зарубіжних та вітчизняних дослідників, як К. Максвел, Дж. Алджео, А. Макмахон, А. Меткаф, Р. Фішер, П. Стекауер, А. Лехрер, П. Хохенхаус, Ю. Зацний, К. Карпова тощо. Наприклад, П. Хохенхаус (2005), Р. Фішер (1998), А. Лехрер (2006) аналізували неологізми як комплексне явище, А. Меткаф (2002) вивчав етимологію неологізмів, їхні словотвірні особливості, К. Карпова (2019) займалась дослідженням неологізмів у сфері харчування та кулінарії.

Мета статті - дослідження особливостей функціонування неологічної лексики, що завдячує своїй появі коронавірусу 2019. Визначення найбільш продуктивних методів формування такої категорії неологізмів є також у фокусі дослідження. Завдання цієї розвідки дослідити словотвірний потенціал коронавірусної термінології, проаналізувати телескопію, словоскладання та афіксацію як продуктивні 
способи формування нової лексики в сучасній англійській мові; розглянути лексичні значення коронавірусної термінології; розподілити неологізми для позначення коронавірусної термінології відповідно до їхніх значень.

\section{Методи дослідження}

У ході дослідження 46 неологізмів, що репрезентують коронавірусну термінологію, були відібрані шляхом суцільної вибірки з таких лексикографічних джерел: About Words - Cambridge Dictionaries Online Blog (CD), Buzzword Archive - Macmillan Dictionary (MD). Дані для дослідження також було отримано із сучасних релевантних онлайн-ресурсів ${ }^{1}$.

Методи дослідження було обрано відповідно до мети, завдань і опрацьованого ілюстративного матеріалу: 1) структурний - для дослідження словотвірних особливостей коронавірусної термінології; 2) семантичний - для вивчення лексичних значень коронавірусної термінологіі; 3) класифікація та систематизація - для розподілу неологізмів коронавірусної термінології відповідно до їх значень.

\section{Виклад основного матеріалу}

Пандемія коронавірусу створила нову картину світу, у межах якої з'явилися численні неологізми для позначення нових категорій людей, способів спілкування, занять, трендів тощо. Як стверджує українська дослідниця неології М. О. Шутова, неологізми є лексичними відповідниками до змін у комунікативних обставинах (Шутова, 2010: 79). Значна кількість інформації на тлі панічних настроїв і браку достовірних та перевірених даних про коронавірус переросли в infodemic (телескопія informational+pandemic) (CD) - великий обсяг інформації про коронавірусну кризу. На думку А. Лехрер, саме телескопія стала одним з найпродуктивніших способів утворення неологізмів у багатьох мовах, зокрема в англійській (Lehrer, 2006: 360).

Передусім родинні й персональні взаємовідносини стали однією з найбільш продуктивних сфер, у яких була створена нова коронавірусна термінологія. Світова пандемія 2019 стала віхою для новонароджених, яких називають coron(n)ials або Covidials (афіксація). Такі «коронадіти» є народженими під час світової пандемії 2019, проте досі незрозуміло, якими є часові межі дати народження таких дітей.

1 The Philadelphia Inquirer. Retrieved from https://www.inquirer.com; Fox news. Retrieved from https://www.foxnews.com; Healthline. Retrieved from https://www.healthline.com etc. 
Усупереч численним жартам у мережі стосовно настання бебі-буму через потребу залишатися вдома, демографи стверджують, що часи суворих економічних криз та нестабільності перешкоджають сплеску народжуваності (Ichimura, 2020). 3 початком коронавірусної пандемії стосунки перетворилися на covidalliances (словоскладання) та covidivorces (телескопія Covid+divorces) (ЕT Bureau, 2020).

Американський професор суспільного здоров'я М. Хокінз стверджує, що деякі люди можуть вирішити сформувати quarantine bubbles (словоскладання) або quaranteams (телескопія quarantine+teams), щоб зменшити негативний психологічний тиск, спричинений затяжною відсутністю соціальної взаємодії під час карантину (Hawkins, 2020). У таких спільнотах, сформованих близькими друзями та родичами, люди спілкуються під час карантину аби задовольнити свої соціальні й емоційні потреби, що отримало назву quaranteam (конверсія $N>V$ ) (Krans, 2020). Різновидами таких «бульбашок» $€$ double bubble та social bubble (словоскладання) (CD). В умовах першої члени двох окремих родин можуть спілкуватися між собою в реальному житті під час карантину, другої - невелика кількість родичів і друзів може зустрічатися в умовах послабленого карантину. Такі quaranteammates (телескопія quarantine+ teammates) обмежують спілкування з іншими з метою мінімізації шансів захворіти на коронавірус (Krans, 2020).

Цікаво, що в Новій Зеландії така концепція обмеженого спілкування під час світової пандемії отримала назву 'bubble concept' (словоскладання / зміна значення). Країна планує відновити транспортне сполучення з Австралією для стимулювання туристичних галузей обох країн, що є важливими для економік обох сусідів, що отримало назву travel bubble (словоскладання) (Olmstead, 2020). Синонімічним до цього є неологізм air bridge (словоскладання) (CD), що ним позначають авіа-коридор між двома країнами, у яких коронавірус перебуває під контролем, що дає змогу туристами з обох країн подорожувати в іншу країну без перебування в режимі самоізоляції після повернення додому. Ще один неологізм коронавірусної термінології, corona corridor (словоскладання) (CD), називає зону, відкриту для здійснення подорожей в умовах карантину.

Закономірно, що лексема 'quarantine' стала часткою багатьох неологічних телескопізмів для позначення нових пандемічних реалій під назвою quarantimes (телескопія quarantine+times). 
Гаджети й додатки, якими вимушені перебувати вдома люди користуються ще більше, ніж раніше, отримали назву quarantech (телескопія quarantine+technologies), поради та тенденції у сферах нового стилю життя, моди, харчування тощо в умовах жорсткого (quarantough (телескопія quarantine+tough) карантину, позначають неологізми quarantips (телескопія quarantine+tips) та quarantrends (телескопія quarantine+trends).

Уряди та компанії можуть пропонувати своїм громадянам і працівникам карантинні гарантії: quarantees (телескопія quarantine+guarantees), що допоможуть їм пережити важкі часи. В онлайн-середовищі з'явилась нова категорія користувачів - quarantrolls (телескопія quarantine+trolls) (ЕT Bureau, 2020). Останні використовують медіапростір для того, щоб пожалітися на свої сумні й одноманітні коронавірусні будні: Blursdays (телескопія blurred+days) іншим користувачам (Lawson, 2020). Для багатьох людей однією з проблем, на яку вони скаржилися під час пандемії, $є$ skin hunger (словоскладання) (CD) - відсутність тілесного контакту з іншими людьми, що є однією з базових потреб. Зважаючи на те, що значна кількість людей проводила багато часу за комп'ютером під час епідемії коронавірусу, у багатьох з них погіршився зір, що отримало назву coronavision (телескопія) (CD). В умовах карантину чимало чоловіків не вважали за потрібне голитися, тому на їхніх обличчях виростали lockdown tache (словоскладання+афереза) (CD) - карантинні вуса.

На щастя, існують способи допомоги людям, що відчувають депресію під час пандемії. Наприклад, психологи й психіатри можуть використовувати формат відеоконференцій для того, щоб допомогти своїм пацієнтам впоратися із психологічними проблемами, викликаними або посиленими коронавірусом. Неологізм teletherapy (CD), сформований шляхом афіксації, позначає цей феномен. Той самий префікс увійшов до складу декількох інших неологізмів, a caмe telework, tele-medicine and tele-socializing (афіксація) (Melamed, 2020). Усі вони позначають певну онлайн-діяльність: роботу, отримання медичної допомоги або спілкування. Ще один доступний спосіб позбавлення себе від стресу під час пандемії - приготування коктейлю quarantini (телескопія quarantine+martini) (MD). Натомість деякі люди можуть відчувати тугу за карантинними часами, що отримала назву lockstalgia (телескопія lockdown+nostalgia) (CD). 
Однак існує певна категорія людей, що нехтують карантинними рекомендаціями та застереженнями і яких зневажливо називають соvidiots (телескопія Covid+idiots) (Lawson, 2020). Людей, що протестують проти носіння масок у публічних місцях, іменують anti-maskers (афіксація) (CD).

Для того, щоб відволіктися від пандемічної рутини й компенсувати брак регулярного спілкування в реальному житті, люди організовують онлайн-вечірки на таких платформах, як Skype або Zoom, що отримали назву covideos (телескопія Covid+videos) й на яких однією 3 топ-тем для обговорення є covexit (телескопія Covid+exit) - міжнародний план послаблення карантину, який було впроваджено в багатьох країнах як відповідь коронавірусній пандемії (Lawson, 2020). Закономірно, люди, які перебували на карантині й були позбавлені звичних способів отримання задоволення, можуть витратити величезну кількість коштів на покупки після закінчення карантину, щоб компенсувати брак шопінгу під час пандемії, що отримало назву revenge spending (словоскладання) (CD). Суголосним цьому неологізму є spendemic (телескопія spend+pandemic) (CD) - явище, коли люди починають витрачати величезні суми грошей на непотрібні речі, що знову ж таки може пояснюватися тривалою відсутністю можливості ходити по магазинах, або ж, навпаки, цей феномен характеризує велику кількість покупок під час карантину для компенсації щоденної рутини.

Під час коронавірусної кризи Zoom став новою платформою для спілкування в мережі для освітян, бізнесменів. Природно, що ця платформа увійшла до складу багатьох неологізмів, пов'язаних з ії використанням. Наприклад, офісні працівники винайшли спосіб одягатися офіційно й повсякденно водночас, що позначає неологізм Zoomwear (словоскладання) (CD). На верхню частину тіла, яку видно на екрані, вони одягають офісний одяг, на нижню - комфортний повсякденний.

Zoombombing (словоскладання) $€$ новою онлайн-тенденцією, яка полягає в тому, що інтернет-тролі переривають приватні відеозустрічі вигуками, непристойними або жорстокими коментарями та/або зображеннями. У деяких випадках грубі незнайомці долучалися до публічних або незакодованих конференцій із власної ініціативи, в інших випадках учні або студенти запрошували незнайомців 
долучитися до їхніх нудних занять у школі або іншому навчальному закладі для того, щоб зірвати заняття: to Zoombomb or Zoom raid (обидва словоскладання) (Conklin, 2020).

На жаль, для когось Zoom може також функціонувати як платформа, на якій може бути оголошено про розрив стосунків: zumping (телескопія Zoom+dumping) (Puhak, 2020).

Коронавірусна криза стала причиною появи нових професій. Наприклад, space marshals (словоскладання) (CD) - це працівники магазинів та бібліотек, які стежать за дотриманням соціальної дистанції відвідувачами. У результаті коронавірусної пандемії чимало працівників були вимушені працювати вдома, що отримало назву $\boldsymbol{W F H}$ (абревіатура work from home) (Lawson, 2020).

Закономірно, що коронавірус у поєднанні з сезонним грипом twindemic (телескопія twin+pandemic) (CD), який очікує світ восени $2020,-$ чи не найбільший страх лікарів та чиновників, що працюють у сфері охорони здоров'я.

\section{Висновки}

Пандемія коронавірусу стала багатим джерелом неологізмів для позначення нових категорій людей, занять, альтернативних способів спілкування, подорожування, тенденцій тощо. Завдяки процесу масової діджиталізації та збільшенню спілкування в соціальних мережах коронавірусна термінологія створюється та поширюється з великою швидкістю. Беручи до уваги той факт, що світова пандемія ще триває, чимало неологізмів для ії позначення продовжуватимуть з'являтися. У межах цього дослідження найбільш продуктивними способами формування коронавірусної термінології виявилися телескопія (46\%), словоскладання (33\%) та афіксація (15\%), було зафіксовано по одному неологізму, що утворилися за допомогою конверсії та поєднання словоскладання й аферези. Крім того, у дослідженні підтверджується теза Ю. А. Зацного про те, що в сучасній англійській мові найбільш продуктивною моделлю словоскладання є утворення бінарних одиниць за моделлю $\mathrm{N}+\mathrm{N}$ (Зацний, 2020: 22): коронавірусні неологізми, утворені таким способом, становлять 63\% від усіх досліджених неологізмів, утворених шляхом словоскладання.

Наші подальші дослідження плануємо присвятити вивченню інших сфер, у яких формуються сучасні англійські неологізми, а саме 
туризму, екології, харчуванню, родинним відносинам, моді тощо, зокрема детально проаналізувати такі способи формування неологізмів, як усічення, конверсія та абревіація.

\section{ЛIТЕРАТУРА}

1. Зацний, Ю. А. (2020). Способи та механізми створення лексико-фразеологічних інновацій англійської мови (2009 - 2019 рр.). Нова білологія, 79, 20-26. 2. Шутова М. О. (2010). Неологізми в сучасній англійській мові. Наук. вісн. кафедри Юнеско КНЛУ. Серія «Філологія. Педагогіка. Психологія», 21, 79-85. 3. About Words - Cambridge Dictionaries Online Blog (n.d.). Retrieved from https://dictionaryblog.cambridge. org. 4. Buzzword Archive - Macmillan Dictionary (n.d.). Retrieved from http://www. macmillandictionary.com/ buzzword/entries/ legsie.html. 5. Conklin, A. (2020). 'Zoombombing' is an inside job? Meeting codes shared on Twitter. Retrieved from https://www. foxbusiness.com/technology/zoombombing-codes-raids-twitter. 6. ET Bureau (2020). Covidivorces, quaranteens and coronials: Why coronavirus puns and neologisms are going viral. Retrieved from https://economictimes.indiatimes.com/magazines/panache/covidivorces-quaranteens-and-coronials-why-coronavirus-puns-and-neologisms-are-going-viral/articleshow/ 75057681.cms. 7. Fischer, R. (1998). Lexical change in present-day English: a corpus-based study of the motivation, institutionalization, and productivity of creative neologisms. Tubingen, Germany: Gunter Narr Verlag Tubingen. 8. Hawkins, M. (2020). Quarantine bubbles - when done right - limit coronavirus risk and help fight loneliness. Retrieved from https://theconversation.com/quarantine-bubbles-when-done-right-limitcoronavirus-risk-and-help-fight-loneliness-140134. 9. Hohenhaus, P. (2005). Lexicalization and institutionalization. In Štekauer P., Lieber R. Handbook of Word-Formation: Studies in Natural Language and Linguistic Theory, 64, (pp. 353-373). Berlin, Germany: Springer. 10. Ichimura, A. (2020). Meet the 'Coronnials' the New Generation of Babies Born During and After COVID-19. Retrieved from https://www.esquiremag.ph/life/health-and-fitness/ coronnials-pandemic-babies-a00304-20200417. 11. Karpova, K. (2019). Structural and semantic characteristics of food-related neologisms in modern English. Advanced Education, 12, 206-211. Retrieved from http://ae.fl.kpi.ua/article/view/144208/172265. 12. Krans, B. (2020). What to Consider Before You Try 'Quaranteaming'. Retrieved from https://www. healthline.com/health-news/what-to-know-before-you-consider-quaranteaming. 13. Lawson, R. (2020). Coronavirus has led to an explosion of new words and phrases - and that helps us cope. Retrieved from https://theconversation.com/coronavirus-has-led-to-an-explosion-of-new-words-and-phrases-and-that-helps-us-cope-136909. 14. Lehrer, A. (2006). Neologisms. In Brown K. (ed.). Encyclopedia of language and linguistics ( $\left.2^{\text {nd }} \mathrm{edn}\right),(\mathrm{pp} .590$ 593). Oxford, England: Elsevier. 15. Melamed, S. (2020). The path to reopening brings anxieties about how to navigate the new normal. Retrieved from https://www.inquirer.com/ news/philadelphia-coronavirus-pandemic-reopening-pennsylvania-yellow-green-phaserestaurants-gyms-20200514.html. 16. Metcalf, A. A. (2002). Predicting New Words: The Secrets of Their Success. Boston, USA: Houghton Mifflin. 17. Olmstead, M. (2020). New Zealand's "Bubble Concept" Is Slowly Letting People Socialize Again. Would It Work in America? Retrieved from https://slate.com/news-and-politics/2020/05/new-zealand-quarantine-bubble-concept-america.html. 18. Puhak J. (2020). 'Zumping' is the terrible breakup trend to emerge amid the coronavirus pandemic. Retrieved from https://www.foxnews. com/lifestyle/zumping-terrible-breakup-trend-coronavirus-pandemic. 


\section{REFERENCES}

1. Zatsnyi, Yu. A. (2020). Sposoby ta mekhanizmy stvorennia leksyko-frazeolohichnyh innovatsii anhliiskoi movy (2009 - 2019) [Ways and mechanisms of coining new English words and set expressions (2009 - 2019)]. Nova filolohiia - New philology, 79, 20-26 [in Ukrainian]. 2. Shutova, M. O. (2010). Neolohizmy v suchasnii anhliiskii movi [Neologisms in modern English]. Naukovyi visnyk UNESCO KNLU. Seriia Filolohiia. Pedahohika. Psykholohiia - Scientific herald of UNESCO Department of KNLU. Philology. Pedagogy. Psychology, 21, 79-85 [in Ukrainian]. 3. About Words - Cambridge Dictionaries Online Blog (n.d.). Retrieved from https:/dictionaryblog.cambridge.org/ [in English]. 4. Buzzword Archive Macmillan Dictionary (n.d.). Retrieved from http://www.macmillandictionary.com/ buzzword/entries/legsie.html [in English]. 5. Conklin, A. (2020). 'Zoombombing' is an inside job? Meeting codes shared on Twitter. Retrieved from https://www.foxbusiness.com/technology/zoombombing-codes-raids-twitter [in English]. 6. ET Bureau (2020). Covidivorces, quaranteens and coronials: Why coronavirus puns and neologisms are going viral. Retrieved from https://economictimes.indiatimes.com/magazines/panache/covidivorces-quaranteens-and-coronials-why-coronavirus-puns-and-neologisms-are-going-viral/articleshow/ 75057681.cms [in English]. 7. Fischer, R. (1998). Lexical change in present-day English: a corpus-based study of the motivation, institutionalization, and productivity of creative neologisms. Tubingen, Germany: Gunter Narr Verlag Tubingen. 8. Hawkins, M. (2020). Quarantine bubbles - when done right - limit coronavirus risk and help fight loneliness. Retrieved from https://theconversation.com/quarantine-bubbles-when-done-right-limitcoronavirus-risk-and-help-fight-loneliness-140134 [in English]. 9. Hohenhaus, P. (2005). Lexicalization and institutionalization. In Štekauer P., Lieber R. Handbook of Word-Formation: Studies in Natural Language and Linguistic Theory, 64, (pp. 353-373). Berlin, Germany: Springer [in English]. 10. Ichimura, A. (2020). Meet the 'Coronnials' the New Generation of Babies Born During and After COVID-19. Retrieved from https://www.esquiremag. ph/life/health-and-fitness/coronnials-pandemic-babies-a00304-20200417 [in English]. 11. Karpova, K. (2019). Structural and semantic characteristics of food-related neologisms in modern English. Advanced Education, 12, 206-211. Retrieved from http://ae.fl.kpi.ua/article/ view/144208/172265 [in English]. 12. Krans, B. (2020). What to Consider Before You Try 'Quaranteaming'. Retrieved from https://www.healthline.com/health-news/what-to-knowbefore-you-consider-quaran teaming [in English]. 13. Lawson, R. (2020). Coronavirus has led to an explosion of new words and phrases - and that helps us cope. Retrieved from https://theconversation.com/coronavirus-has-led-to-an-explosion-of-new-words-andphrases-and-that-helps-us-cope-136909 [in English]. 14. Lehrer, A. (2006). Neologisms. In Brown K. (ed.). Encyclopedia of language and linguistics ( ${ }^{\text {nd }}$ edn), (pp. 590-593). Oxford, England: Elsevier [in English]. 15. Melamed, S. (2020). The path to reopening brings anxieties about how to navigate the new normal. Retrieved from https://www.inquirer.com/news/ philadelphia-coronavirus-pandemic-reopening-pennsylvania-yellow-green-phase-restaurants-gyms-20200514.html [in English]. 16. Metcalf, A. A. (2002). Predicting New Words: The Secrets of Their Success. Boston, USA: Houghton Mifflin [in English]. 17. Olmstead, M. (2020). New Zealand's “Bubble Concept” Is Slowly Letting People Socialize Again. Would It Work in America? Retrieved from https://slate.com/news-and-politics/2020/05/new-zealand-quarantine-bubble-concept-america.html [in English]. 18. Puhak, J. (2020). 'Zumping' is the terrible breakup trend to emerge amid the coronavirus pandemic. Retrieved from 
https://www.foxnews.com/lifestyle/zumping-terrible-breakup-trend-coronavirus-pandemic [in English].

Сандига Лілія Олександрівна - кандидат філологічних наук, асистент кафедри іноземних мов економічного факультету, Київський національний університет імені Т. Шевченка; вул. Васильківська, 90а, Київ, 03022, Україна.

Tel.: +380508186450

E-mail:lilyflower1308@gmail.com

https://orcid.org/0000-0002-3124-664X

Sandyha Liliia Oleksandrivna - Ph.D. in Philology, Assistant Professor at the Department of Foreign Languages, Faculty of Economics, Taras Shevchenko National University of Kyiv; Vasylkivska Str., 90a, Kyiv, 03022, Ukraine.

Свиридюк Тетяна Володимирівна - кандидат філологічних наук, асистент кафедри іноземних мов економічного факультету, Київський національний університет імені Т. Шевченка; вул. Васильківська, 90а, Київ, 03022, Україна.

E-mail: svyrydiuk.t@gmail.com

Tel.: +390979538057

https://orcid.org/0000-0001-9482-8228

Svyrydiuk Tetiana Volodymyrivna - PhD in Philology, Assistant Professor at the Department of Foreign Languages, Faculty of Economics of Taras Shevchenko National University of Kyiv; Vasylkivska Str., 90a, Kyiv, 03022, Ukraine.

Романиук Світлана Валеріївна - асистент кафедри іноземних мов економічного факультету, Київський національний університет імені Т. Шевченка; вул. Васильківська, 90а, Київ, 03022, Україна.

E-mail: svitlana_romanchuk@ukr.net

Tel.: +380975929439

https://orcid.org/0000-0002-4853-8892

Romanchuk Svitlana Valeriivna - Assistant Professor at the Department of Foreign Languages, Faculty of Economics of Taras Shevchenko National University of Kyiv; Vasylkivska Str., 90a, Kyiv, 03022, Ukraine.

Надійшла до редакції 17 вересня 2020 року

\section{CITATION}

ДСТУ 8302:2015: Сандига Л. О., Свиридюк Т. В., Романчук С. В. Англійські неологізми коронавірусної кризи. Лінгвістичні дослідження: зб. наук. пр. Харк. нац. пед. ун-ту імені Г. С. Сковороди. Харків, 2020. Вип. 53. С. 117-126. DOI: https:/doi.org/ $10.34142 / 23127546.2020 .53 .11$

АРА: Сандига, Л. О., Свиридюк, Т. В., \& Романчук, С. В. (2020). Англійські неологізми коронавірусної кризи. Лінгвістичні дослідження, 53, 117-126. DOI: https://doi. org/10.34142/23127546.2020.53.11 